Didaktik : Jurnal Pendidikan Guru Sekolah Dasar, ISSN : 24775673

Sekolah Tinggi Keguruan dan IImu Pendidikan Subang

Volume IV Nomor 2, Desember 2018

\title{
PENGEMBANGAN MEDIA PERMAINAN MONAYA UNTUK MENINGKATKAN PEMAHAMAN MULTIKULTURAL ANAK USIA 7-8 TAHUN
}

\author{
Melisa Indah Firdausi ${ }^{1}$, Hapidin², Tuti Tarwiyah ${ }^{3}$ \\ 1,2,3Pascasarjana PAUD Universitas Negeri Jakarta \\ 1melisa.firdausi@gmail.com, 2hapidin1964@gmail.com, \\ 3tutitarwiyah@yahoo.com
}

\begin{abstract}
The purpose of this study is to improve the multicultural understanding of children aged 7-8 years through the MONAYA game media. MONAYA's game media is a game of Cultural Monopoly which has content of cultural or multicultural diversity and has printed on large banners and makes children as pawns using dice and supporting cards of large size so as to attract children's interest in teaching and learning activities and become wrong an alternative learning media. This study uses ADDIE (Analyze, Design, Develop, Implement, Evaluate) methods and has been tested through oneon-one trials), small group trials and field group trials and has been validated by early childhood education experts, media experts and multicultural experts. There is an increase in the results of very high child pre-test and post-test and enthusiastic activities which indicate that the MONAYA game media is suitable to be used to increase multicultural understanding of children aged 7-8 years.
\end{abstract}

Keywords: Monopoly Games, Multicultural, Primary Education

\begin{abstract}
ABSTRAK
Penelitian ini merupakan Penelitian dan Pengembangan (Research and Development) yang bertujuan untuk meningkatkan pemahaman multikultural anak usia 7-8 tahun melalui media permainan MONAYA. Media permainan MONAYA merupakan permainan Monopoli Budaya yang memiliki konten mengenai keberagaman budaya atau multikultural dimana monopoli tersebut dicetak pada banner besar dan menjadikan anak sebagai pion dengan menggunakan dadu dan kartu-kartu pendukung dengan ukuran besar sehingga dapat menarik minat anak dalam kegiatan belajar mengajar dan menjadi salah satu alternatif media pembelajaran. Penelitian ini menggunakan metode ADDIE (Analyze, Design, Develop, Implement, Evaluate) dan telah diujicobakan melalui uji coba satu-satu (one to one), uji coba kelompok kecil (small group) dan uji coba kelompok besar (field group) serta telah divalidasi oleh pakar pendidikan anak usia dini, pakar media dan
\end{abstract}


pakar multikultural. Adanya peningkatan pada hasil kegiatan pre-test dan post-test dan antusias anak yang sangat tinggi yang menunjukkan bahwa media permainan MONAYA layak digunakan untuk meningkatkan pemahaman multikultural pada anak usia 7-8 tahun.

Kata Kunci: Permainan Monopoli, Multikultural, Pendidikan Dasar

\section{A. Pendahuluan}

Indonesia

merupakan

negara kepulauan yang memiliki beraneka ragam kebudayaan di setiap daerahnya, mulai dari suku, bahasa daerah, adat istiadat, kepercayaan, kesenian daerah, dan budaya lainnya. Meskipun penuh dengan keragaman budaya, Indonesia tetap satu sesuai dengan semboyannya, "Bhineka Tunggal Ika" yang memiliki arti "meskipun berbeda-beda, tetapi tetap satu jua”. Artinya, perbedaan-perbedaan budaya di Indonesia tidak menjadikan Indonesia menjadi terpecah belah melainkan menjadi satu untuk lebih kuat. Selain itu, keragaman budaya ini pun dapat menjadi ciri khas Indonesia untuk diketahui secara global. Oleh karena itu, bangsa Indonesia dapat terus berupaya untuk melestarikan budaya agar tetap terjaga menjadi kebudayaan orisinil Negara Indonesia.
Dewasa ini, kendala yang dimiliki bangsa Indonesia adalah masuknya budaya asing yang berkembang sangat pesat. Akibatnya, banyak pengaruh global yang tidak bisa direspon secara seimbang oleh masyarakat Indonesia, bahkan tidak jarang masyarakat Indonesia yang bangga terhadap kebudayaan yang dimiliki oleh bangsa lain. Oleh sebab itu, salah satu penanganan yang dapat dilakukan untuk mencegah terjadinya pengaruh dari budaya asing tersebut adalah dengan mengenal budaya Indonesia terlebih dahulu. Pengenalan budaya dapat ditanamkan sejak dini agar dapat menjadi penerus bangsa yang tidak kehilangan identitas bangsanya sendiri.

Pengenalan budaya Indonesia sejak dini merupakan salah satu upaya pelestarian budaya seperti yang terdapat pada Peraturan Menteri Pendidikan dan 
Kebudayaan Republik Indonesia

Nomor 10 Tahun 2014 tentang

Pedoman Pelestarian Tradisi.

Pelestarian Tradisi adalah upaya perlindungan, pengembangan dan pemanfaatan suatu kebiasaan dari kelompok masyarakat pendukung kebudayaan yang penyebaran dan pewarisannya berlangsung secara turun temurun. Oleh karena itu, diperlukan suatu inovasi agar anak usia dini dapat mengenal budaya Indonesia sehingga meningkatkan pemahaman mereka akan budaya Indonesia.

Penelitian yang relevan terkait media yang digunakan dalam mengenalkan keragaman budaya pada anak adalah dengan menggunakan buku Pop-Up oleh Adiza Belva, et.al. (2015) dengan judul "POBUNDO (Pop-Up Budaya Indonesia) sebagai Media Pembelajaran Berbasis Kebudayaan untuk Siswa Kelas IV Sekolah Dasar". Hasil dari penelitian ini menunjukkan bahwa kedua kelas mengalami kenaikan yang cukup signifikan antara pretest dan setelah mendapat perlakuan sehingga media Pop-Up Budaya Indonesia adalah media pembelajaran berbasis kebudayaan yang layak, menarik dan efektif untuk mengenalkan kebudayaan Indonesia. Dengan media pembelajaran yang menarik dapat meningkatkan minat anak dalam belajar dan memahami kebudayaan Indonesia.

Dari hasil studi pendahuluan yang dilakukan di dua sekolah dimana masing-masing sekolah memiliki jumlah siswa sebanyak 75 siswa dan 46 siswa, diketahui bahwa anak kelas 1 SD baru mulai mengenal keberagaman yang ada di sekitar yaitu perbedaan agama, perbedaan suku dan perbedaan sifat teman sekelas. Adapun media yang digunakan oleh SDN 13 Duren Sawit dalam pemberian materi multikultural pada anak didiknya berupa media gambar, lagu dan audio visual. Sedangkan pada pembelajaran yang sama SDN 02 Duren Sawit menggunakan media gambar dan buku cerita. Berdasarkan hasil wawancara tersebut, diketahui bahwa media permainan belum digunakan sebagai media pembelajaran multikultural di kedua sekolah tersebut. 
Didaktik : Jurnal Pendidikan Guru Sekolah Dasar, ISSN : 24775673

Sekolah Tinggi Keguruan dan IImu Pendidikan Subang

Volume IV Nomor 2, Desember 2018

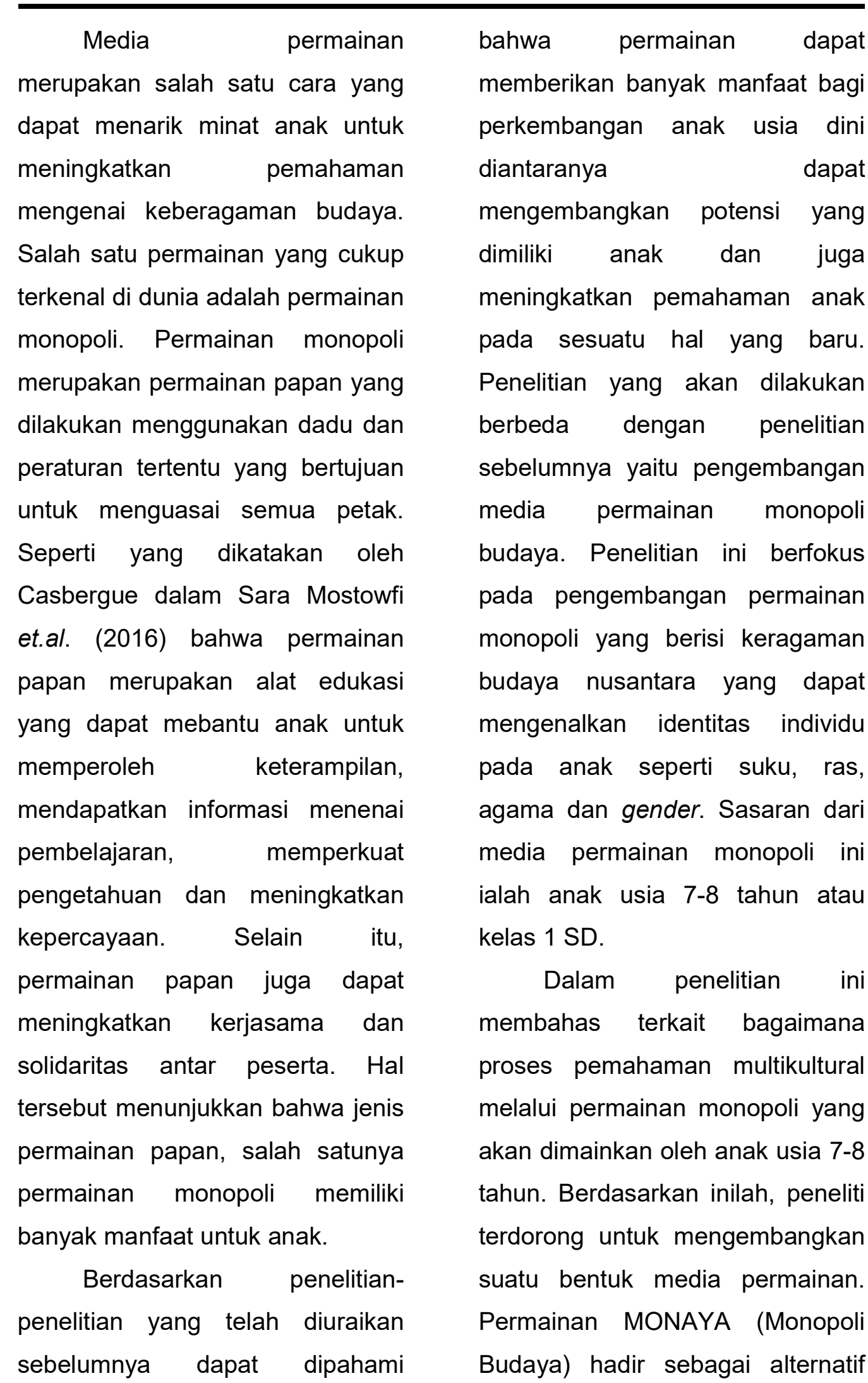


Didaktik : Jurnal Pendidikan Guru Sekolah Dasar, ISSN : 24775673

Sekolah Tinggi Keguruan dan IImu Pendidikan Subang

Volume IV Nomor 2, Desember 2018

untuk permasalahan anak agar dapat semakin mencintai Indonesia dengan mengenal keanekaragaman budayanya terlebih dahulu.

\section{B. Metode Penelitian}

Pada penelitian ini, model yang akan dikembangkan adalah berupa media permainan monopoli budaya yang didesain semenarik mungkin yang di dalamnya terdapat unsur multikultural yang diwakili oleh orang-orang yang menggunakan pakaian adat. Selain itu, kelebihan model permainan monopoli budaya ini adalah sebagai alat bantu dalam kegiatan belajar mengajar untuk mengenalkan keragaman budaya.

Karakteristik media permainan monopoli yang akan dikembangkan dan diaplikasikan adalah permainan monopoli budaya yang terdapat unsur pengenalan identitas diri yang mencakup suku, ras, agama dan jenis kelamin yang diwakili oleh pakaian adat, kartu rumah adat, pendopo, dan kartu-kartu lainnya yang menunjukkan keragaman budaya yang ada di Indonesia serta peraturan-peraturan yang terkait dengan budaya Indonesia.

Media permainan Monaya merupakan penelitian dan pengembangan (Research and Development) produk media pembelajaran. Menurut Semiawan (2007), penelitian dan pengembangan digunakan untuk menjembatani kesenjangan antara penelitian dan praktik pendidikan. Pendapat tersebut menjelaskan bahwa penelitian dan pengembangan ini bertujuan untuk memberikan solusi terhadap permasalahan pendidikan.

Semiawan

(2007) menjelaskan bahwa penelitian dan pengembangan dalam bidang pendidikan diarahkan pada pengembangan produk yang efektif bagi keperluan sekolah, dan merupakan penelitian terapan. Artinya penelitian ini dapat diterapkan dan digunakan dalam pendidikan.

Pendekatan yang digunakan dalam penelitian ini adalah menggunakan model ADDIE (Analyze, Design, Develop, Implement, and Evaluation). Model ADDIE dipilih karena model ADDIE 
memberikan arahan secara rinci mengenai langkah-langkah apa saja yang akan dilakukan selama penelitian pengembangan, mulai dari mencari sumber kesenjangan antara fakta lapangan dan keadaan yang sesuai harapan, membuat rancangan produk sampai biayanya, mengembangkan media hingga membuat buku petunjuk untuk guru dan murid, mempersiapkan guru dan murid untuk tahap implementasi hingga pemilihan alat evaluasi pun dibahas secara rinci. Oleh karena itu, model ADDIE merupakan model yang tepat untuk digunakan sebagai panduan penelitian pengembangan media. Model penelitian dan pengembangan ini bertujuan untuk menghasikan suatu produk berupa media permainan MONAYA yang digunakan untuk meningkatkan pemahaman multikultural anak usia 7-8 tahun.

\section{Pada} penelitian pendahuluan, yang pertama dilakukan adalah analisis kebutuhan yang bertujuan untuk mengetahui kebutuhan siswa akan sebuah media yang mampu membantu dalam meningkatkan pemahaman multikultural pada siswa, dan sebagai alat bantu agar siswa dapat mengenal keragaman budaya lebih dalam. Pengembangan model media permainan monopoli ini dapat diterapkan pada anak di usia 7-8 tahun.

Studi lapangan pra penelitian yang dilakukan oleh peneliti yaitu tanpa melibatkan diri dalam proses pembelajaran. Studi lapangan Pra penelitian dilakukan di 2 SD yaitu SDN 02 Duren Sawit Jakarta Timur dan SD 13 Duren Sawit Jakarta Timur. Pada studi lapangan pra penelitian tersebut, peneliti melakukan wawancara dengan guru dan kepala sekolah untuk mengetahui sejauh mana pemahaman anak mengenai multikultural. Hasil dari studi lapangan Pra penelitian menunjukkan bahwa masih kurangnya pemahaman anak mengenai multikultural. Selain itu, media dan metode yang digunakan untuk mengenalkan budaya pada anak pun dirasa kurang optimal sehingga membutuhkan media atau metode pengajaran yang 
dapat menarik minat anak untuk mempelajari keragaman budaya tersebut.

\section{Hasil dan Pembahasan}

Penelitian pengembangan model dimulai dengan mengidentifikasi atau menganalisa kebutuhan dimana hasil dari analisa kebutuhan tersebut dapat digunakan untuk menciptakan atau mengembangkan model (baik produk maupun prosedur/proses) secara terencana, diuji di lapangan secara sistematis, dievaluasi, kemudian diperbaiki hingga pada akhirnya menjadi sebuah model yang memenuhi kriteria yang spesifik terkait efektivitas, kualitas atau standar lainnya, serta bermanfaat bagi penggunanya. Model yang dihasilkan dalam penelitian dan pengembangan ini berupa produk media permainan monopoli yang dinamakan MONAYA (Monopoli Budaya) yang dibuat dalam rangka untuk meningkatkan

pemahaman multikultural berupa identitas individu (suku, ras, agama dan jenis kelamin) pada anak usia 7-8 tahun.
Media permainan MONAYA ini merupakan media berbentuk permainan monopoli yang diinovasi dengan menggunakan cetakan ukuran besar sebagai alat bantu penambah daya tarik, semangat dan motivasi belajar yang bertujuan agar materi yang disampaikan lebih mudah dipahami dan lebih terkesan. Konsep media ini dikembangkan berdasarkan budaya Indonesia dan teori-teori multikultural untuk anak usia dini sehingga media permainan yang dihasilkan sesuai dengan anak usia dini khususnya anak usia 7-8 tahun.

Dalam metode penelitian dan pengembangan, diperlukan validasi dari beberapa pakar seperti pakar pendidikan anak usia dini, pakar media dan pakar materi atau pakar multikultural. Selain itu, dibutuhkan juga uji coba mulai dari uji coba satu-satu (one to one), uji coba kelompok kecil (small group) dan uji coba kelompok besar (field group). Untuk mendapatkan validasi dari pakar, Peneliti menyerahkan kuesioner kepada para pakar atau ahli yang telah disesuaikan dengan bidang 
masing-masing yang kemudian untuk diisi dan diberi saran maupun tanggapan terkait penelitian pengembangan ini. Berikut merupakan hasil penilaian dari pakar/ahli dalam rangka uji kelayakan media permainan MONAYA:

Tabel 1 Hasil Penilaian Kelayakan Media oleh Pakar/Ahli

\begin{tabular}{cccc}
\hline No. & \multicolumn{3}{c}{ Hasil Penilaian } \\
\cline { 2 - 4 } & Pakar/Ahli & $\begin{array}{c}\text { Presentase } \\
\text { Kelayakan }\end{array}$ & Keterangan \\
\hline 1 & $\begin{array}{c}\text { Pendidikan } \\
\text { Anak Usia } \\
\text { Dini }\end{array}$ & $94.4 \%$ & $\begin{array}{c}\text { Sangat } \\
\text { Layak }\end{array}$ \\
2 & Multikultural & $100 \%$ & $\begin{array}{l}\text { Sangat } \\
\text { Layak } \\
\text { Sangat } \\
\text { Layak }\end{array}$ \\
3 & Media & $100 \%$ & \\
& & &
\end{tabular}

Berdasarkan hasil uji dari para pakar atau ahli di atas, maka media permainan MONAYA layak dikembangkan sebagai media untuk meningkatkan pemahaman multikultural anak usia 7-8 tahun di kota Jakarta Timur.

Selain uji teoritik, uji kelayakan selanjutnya didasarkan pula melalui uji empiris. Uji empiris dilakukan melalui uji coba satusatu (one to one) dan uji coba kelompok kecil (small group). Uji empiris tersebut dilakukan dengan responden anak usia 7-8 tahun. Peneliti memperhatikan, mengamati dan mencatat respon dari responden dari uji coba media permainan MONAYA. Responden pada uji coba satu-satu (one to one) berjumlah 5 orang dan responden pada uji coba kelompok kecil (small group) berjumlah 10 orang. Hasil pengamatan dari kedua uji coba tersebut menunjukkan respon yang positif, anak-anak sangat antusias dan tertarik terhadap media permainan MONAYA.
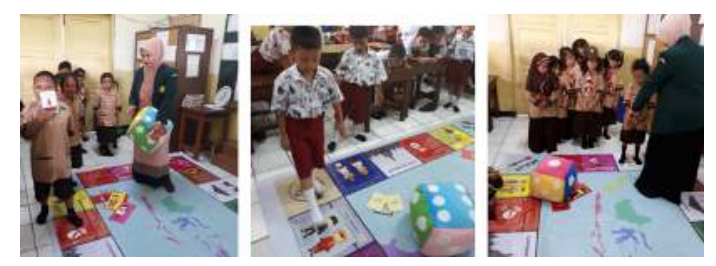

Gambar 1 Uji coba kelompok kecil (Small Group)

Setelah penilaian kelayakan media oleh pakar/ahli, peneliti melakukan penelitian dan memperoleh data pre-test dan post-test dari 32 responden, dengan hasil rata-rata nilai pre-test adalah sebesar 70,469. Sedangkan rata-rata nilai post test adalah sebesar 82,031. Selama uji lapangan tersebut, mengalami kenaikan nilai rata-rata sebesar 
11,562. Peningkatan nilai anak dalam memahami multikultural menunjukkan bahwa media permainan MONAYA dapat diterima sebagai salah satu media untuk mengenalkan multikultural atau budaya Indoneisa kepada anak usia dini.

Selanjutnya, dalam penelitian media permainan MONAYA ini, uji efektivitas penggunaan media dihitung menggunakan uji $\mathrm{t}$ berpasangan melalui SPSS versi 16 dengan menggunakan rumus paired sample t-test yang merupakan uji dari dua sampel berpasangan. Sampel berpasangan adalah sampel yang sama tetapi mendapatkan perlakuan yang berbeda, dalam penelitian ini adalah pre-test dan post-test.

Sebelum pengolahan data dilaksanakan, ada langkah yang terlebih dahulu harus dilakukan yaitu menyusun hipotesis, hipotesis dalam penelitian ini adalah sebagai berikut :

HO : Tidak ada perbedaan ratarata dari hasil pre-test dan post-test yang dilakukan
H1 : Terdapat perbedaan ratarata dari hasil pre-test dan post-test yang dilakukan

Hasil analisis data t-test berpasangan atau paired test dengan menggunakan aplikasi SPSS versi 16 diperoleh hasil thitung sebesar -9.492 dengan nilai signifikansi (2-tailed) sebesar 0.000 sehingga $0.000<0.05$. Hasil dari nilai signifikansi (2-tailed) sebesar 0.000 yang lebih kecil dari 0.05 menyimpulkan bahwa media permainan MONAYA efektif digunakan untuk meningkatkan pemahaman multikultural pada anak usia 7-8 tahun.

Metode pengajaran yang dilakukan pada kegiatan belajar mengajar sehari-hari mempengaruhi suasana hati anak ketika belajar. Dengan metode bermain dalam pembelajaran dapat menarik minat anak untuk belajar. Pada penelitian ini, metode bermain dilakukan untuk membantu anak dalam meningkatkan pemahaman terkait multikultural. Permainan MONAYA (Monopoli Budaya) hadir sebagai salah satu bentuk permainan monopoli dengan aturan 
permainan yang sangat unik sehingga anak tertarik untuk bermain sambil belajar. Hal ini sejalan dengan pernyataan $M$. Fadillah (2017) yang mengatakan bahwa bermain merupakan kebutuhan alamiah anak usia dini. Selain sebagai aktivitas bersenang-senang, bermain juga merupakan kegiatan belajar bagi anak karena anak usia dini belajar melalui bermain. Banyak manfaat yang dapat diambil dari aktivitas bermain sehingga bermain tidak bisa dilepaskan dari anak usia dini. Melalui bermain, seorang anak dapat belajar berbagai hal baru yang belum dikuasai sebelumnya. Oleh karena itu, dapat disimpulkan bahwa penggunaan permainan MONAYA merupakan kegiatan yang sesuai dengan perkembangan anak usia dini.

\section{Media permainan MONAYA} merupakan salah satu permainan papan yang memiliki banyak manfaat untuk digunakan oleh anak. Seperti yang dikatakan oleh Casbergue dalam Sara Mostowfi et.al, (2016) dalam penelitiannya, bahwa permainan papan merupakan alat edukasi yang dapat membantu anak untuk memperoleh keterampilan, mendapatkan informasi mengenai pembelajaran, memperkuat pengetahuan dan meningkatkan kepercayaan. Selain itu, permainan papan juga dapat meningkatkan kerjasama dan solidaritas antar peserta. Sehingga dapat disimpulkan bahwa permainan MONAYA merupakan permainan yang tepat untuk meningkatkan suatu pemahaman pada anak usia dini.

Selain itu, media permainan MONAYA pun memiliki tampilan media visual yang menarik sehingga dapat mempengaruhi minat anak dalam proses penggunaannya. Hal ini sejalan dengan yang dikatakan oleh Umar dalam penelitiannya, bahwa media dalam pembelajaran memegang peranan penting dalam kegiatan belajar mengajar karena dapat meningkatkan dan mengarahkan perhatian anak sehingga menimbulkan motivasi belajar. Oleh karena itu, dapat disimpulkan bahwa media permainan MONAYA merupakan media yang tepat 
untuk meningkatkan motivasi anak dalam memperoleh pengetahuan.

Penelitian

dan

pengembangan ini dilakukan dengan tujuan untuk menghasilkan sebuah produk berupa media permainan MONAYA (Monopoli Budaya) yang dapat digunakan untuk meningkatkan pemahaman multikultural pada anak usia 7-8 tahun. Media permainan MONAYA ini memiliki satu buah papan besar yang dicetak pada banner dan produk penunjang lainnya seperti dadu dan kartu-kartu dengan ukuran besar serta buku panduan sebagai pedoman permainan. Hal ini sesuai dengan metode penelitian dan pengembangan model (Research and Development) yang merupakan metode penelitian dengan tujuan untuk menghasilkan produk tertentu, dan menguji keefektifan produk tersebut. Artinya untuk dapat menghasilkan produk permainan MONAYA ini, telah melalui proses analisis kebutuhan, validasi pakar dan uji efektivitas produk tersebut agar dapat mencapai tujuan awal pembuatan produk ini.
Hasil validasi pakar diperoleh kesimpulan bahwa media permainan MONAYA layak digunakan sebagai media pembelajaran pada anak usia dini untuk meningkatkan pemahaman multikultural. Selain itu, dari hasil uji efektivitas didapatkan kesimpulan bahwa nilai thitung sebesar -9.492 dengan nilai signifikansi (2-tailed) sebesar 0.000 sehingga $0.000<0.05$. Hasil dari nilai signifikansi (2-tailed) sebesar 0.000 yang lebih kecil dari 0.05 menyimpulkan bahwa media permainan MONAYA efektif digunakan untuk meningkatkan pemahaman multikultural pada anak usia 7-8 tahun.

\section{Kesimpulan}

Penelitian ini merupakan jenis penelitian dan pengembangan yang menggunakan metode ADDIE (Analyze, Design, Develop, Implement, Evaluate) dan menghasilkan suatu model atau produk berupa media permainan MONAYA yaitu permainan monopoli budaya yang dicetak di banner besar dengan 
menggunakan anak sebagai

pionnya. Tujuan dari penelitian dan

pengembangan media permainan

MONAYA ini adalah untuk

meningkatkan

pemahaman

multikultural pada anak usia 7-8

tahun. Pemahaman multikultural

yang dimaksud adalah identitas

individu yang terdiri dari suku, ras,

agama dan jenis kelamin. Pada

penelitian ini terdapat uji kelayakan

melalui proses uji pakar/ahli, uji coba satu-satu (one to one), uji

coba kelompok kecil (small group)

dan uji coba kelompok besar (field group) sehingga didapatkan hasil bahwa media permainan MONAYA dinilai layak untuk meningkatkan pemahaman multikultural pada anak usia 7-8 tahun.

Pada uji efektivitas, didapatkan hasil bahwa media permainan MONAYA dinilai efektif untuk meningkatkan pemahaman multikultural pada anak usia 7-8 tahun berupa identitas individu yang mencakup suku, ras, agama dan jenis kelamin. Keefektifan media permainan MONAYA dapat dilihat melalui adanya perbedaan antara sebelum dan sesudah dilakukannya media permainan
MONAYA tersebut. Terdapat kegiatan pre test dan post test yang bertujuan untuk mengetahui nilai yang diperoleh anak antara sebelum dan sesudah media permainan MONAYA dilakukan. Hasil kegiatan pre test dan post test tersebut menunjukkan nilai post test anak lebih tinggi daripada nilai pre test, sehingga dapat disimpulkan bahwa terjadi peningkatan nilai yang berarti pemahaman anak terhadap multikultural berupa identitas individu yang mencakup suku, ras, agama dan jenis kelamin meningkat setelah bermain media permainan MONAYA.

$\begin{array}{cr}\text { Peneliti } & \text { selanjutnya } \\ \text { diharapkan dapat melakukan }\end{array}$ penelitian-penelitian yang lebih berinovasi dan kreatif lagi baik dari segi konten maupun media atau produk yang diciptakan, terutama media terkait pengenalan keberagaman budaya Indonesia agar anak mengenal dan mencintai Negara Indonesia sejak dini. 


\section{DAFTAR PUSTAKA}

Belva, Adiza,et al. (2015). POBUNDO (Pop-Up Budaya Indonesia) sebagai Media Pembelajaran Berbasis Kebudayaan untuk Siswa Kelas IV Sekolah Dasar. PELITA Volume X, Nomor 1, April

Fadillah, M. (2017). Bermain dan Permainan Anak Usia Dini. Jakarta : Kencana

Mostowfi, Sara, et. al. (2016). Designing Playful Learning by Using Educational Board Game for Children In the Age Range of 7-12: (A Case Study : Recycling and Waste Separation Education Board Game). International Journal of Environmental \& Science Education vol. 11 No. 12.

Peraturan Menteri Pendidikan dan Kebudayaan Republik Indonesia Nomor 10 Tahun 2014 tentang Pedoman Pelestarian Tradisi Semiawan,Conny R. (2007). Catatan Kecil tentang penelitian dan Pengembangan IImu Pengetahuan. Jakarta : Kencana Prenada Media Group 